\title{
Lowering blood pressure effect of Apium graviolens (seledri) and Orthosiphon stamineus benth (kumis kucing) in mild and moderate hypertension
}

\author{
Fadilah Supari
}

\begin{abstract}
Abstrak
Di Indonesia Apium graviolens (seledri) dan Orthosiphon stamineus benth (kumis kucing) sudah lama dikenal sebagai bahan obat tradisional yang dipercaya dapat menurunkan tekanan darah. Pada saat ini sudah beredar di pasaran Indonesia kemasan fitofarmaka yang berisi kombinasi antara dua bahan tersebut. Oleh karena itu perlu dilakukan penelitian untuk mengetahui efektifitas dan efek samping terhadap penderita hipertensi ringan dan sedang. Penelitian dilakukan di daerah Monica Jakarta di Jakarta Selatan 3 Juli sampai 29 Oktober 2001 terhadap penderita hipertensi ringan dan sedang dengan randomized double blind controlled trial. Kelompok pertama (72 subjek) mendapat fitofarmaka (Tensigard ${ }^{(3)}$ yang berisi seledri dan kumis kucing) sebanyak $3 \times 250$ mg, sedangkan kelompok kedua (70 subjek) diberikan Amlodipine I x $5 \mathrm{mg}$. Pengamatan dilakukan selama 12 minggu dan parameter yang diukur adalah tekanan darah sistolik maupun diastolik, kadar lipid plasma, kadar gula darah sebelum dan sesudah perlakuan, serta kadar elektrolit tiap dua minggu perlakuan. Hasil penelitian menunjukkan bahwa pemberian fitofarmaka selama dua belas minggu menurunkan tekanan darah sistolik (TDS) maupun diastolik (TDD) setara dengan Amlodipine (TDS 24,72 $\pm 1.63 \mathrm{mmHg}$ vs 26,27 $\pm 2.18 \mathrm{mmHg}, P>0,05 ;$ TDD $10,00 \pm 0.96 \mathrm{mmHg}$ vs $9.49 \pm 1.37 \mathrm{mmHg} P>0.05$ ). Di samping itu pemberian fitofarmaka dua belas minggu tidak mempengaruhi kadar elektrolit plasma, kadar lipid plasma maupun kadar gula darah. Selain itu tidak ditemukan efek samping yang berarti pada pemberian fitofarmaka maupun Amlodipine selama penelitian berlangșung. Pada penelitian ini dapat disimpulankan bahwa fitofarmaka dapat menurunkan tekanan darah sistolik maupun diastolik setara dengan Amlodipine serta tidak ditemukan efek samping yang berarti bagi penderita hipertensi ringan dan sedang selama waktu penelitian. (Med J Indones 2002; 11: 195-201)
\end{abstract}

\begin{abstract}
In Indonesia Apium graviolens and Orthosiphon stamineus benth have been used to as traditional medicines to lower blood pressure. Since at present time is available as a combination of those phytopharmaca in the market, therefore, it is necessary to conduct a study to evaluate the effectivity and side effects of those phytopharmaca toward hypertensive subjects. A randomized double blind controlled trial was conducted at area of Monica - Jakarta in South of Jakarta from 3 July until 29 October 2001 toward mild and moderate hypertensive subjects. The first group (72 subjects) received phytopharmaca (Tensigard which contains Apium graviolens and Orthosiphon stamineus benth) $3 \times 250 \mathrm{mg}$, while the second group (70 subjects) had Amlodipine $1 \times 5 \mathrm{mg}$. Observation were conducted for 12 weeks, and the parameter observed were systolic and diastolic blood pressure (SBP and DBP), plasma lipid, blood glucose before and after treatment, and electrolyte with two week intervals. The Results revealed that the phytopharmaca treatment for 12 weeks lowered SBP and DBP equivalent to Amlodipine (SBP $24.72 \pm 1.63 \mathrm{mmHg}$ vs $26.27 \pm 2.18 \mathrm{mmHg} ; P>0.05 ; D B P 10.00 \pm 0.96 \mathrm{mmHg}$ vs $9.49 \pm 1.37 \mathrm{mmHg} ; P$ $>0.05)$. Phytopharmaca treatment for 12 weeks did not influence plasma electrolyte, as well blood glucose levels. There was not a significant side effects noted for both phytopharmaca and Amlodipine during the study period. In conclusion, the trial reveals that the phytopharmaca lowered systolic and diastolic blood pressure equivalent with Amlodipine among mild and moderate hypertensive subjects. During the study period there was not a significant side effect noted. (Med I Indones 2002; 11: 195-20I)
\end{abstract}

Keywords: blood pressure, phytopharmaca, side effect, plasma electrolytes

Hypertension is an important risk factor for coronary heart disease. Several studies in Indonesia reported

Department of Cardiology, Faculty of Medicine, University of Indonesia, and National Cardiovascular Center Harapan Kita Hospital, Jakarta, Indonesia that the hypertensive prevalence ranged from $17 \%$ to 22\%.' Based on Joint National Committee (USA) consensus VI, ${ }^{2}$ the first step of hypertension treatment is a life style changes. If the life style changes failed, pharmacological treatment is given. 
A number of Indonesian people consume some traditional herbs to treat hypertension. One of the phytopharmaca for treating hypertension is Tensigard ${ }^{\circledR}$ (a product of PT Phapros, Semarang) which contains Apium graviolens and Orthosiphon stamineus benth. The previous phase one and $\mathrm{two}^{3,4}$ trial proved that these phytopharmaca lowered blood pressures significantly. ${ }^{4}$ These phytopharmaca contain active compounds which able to lower blood pressure, i.e. apigenin and manitol which have function as calcium antagonist and diuretics respectively.

Orthosiphon stamineus benth is predicted have a dominant diuretic effect to lower high pressure. ${ }^{6-7}$ Therefore, this study is to prove to what extend these phytopharmaca lowering blood pressure among mild and moderate hypertensive subjects, and to investigate some related side effects.

\section{METHODS}

This study was conducted at area Monica-Jakarta in South of Jakarta from July 3 until October 292001. Subjects were derived from MONICA (Monitoring of Trend in Cardiovascular Disease) Jakarta population study. The population consisted of 1800 subjects, where 400 subjects suffered from high blood pressure. There were one hundred and sixty subjects suffering from mild or moderate hypertensive who were eligible for this study based on inclusion and exclusion criteria and those who state to join the study. The inclusion criteria were subjects aged $25-70$ years, essential hypertension, did not take anti hypertensive treatment for the last two weeks.

Hypertension was defined as follows: Diastolic blood pressure $95-114 \mathrm{mmHg}$, or systolic blood pressure $160-199 \mathrm{mmHg}$. Blood pressure was derived from average of two measurements in sitting position. While exclusion criteria were: (1) Pregnant or lactating women; (2) Women who were taking hormonal contraceptive methods; (3) Subjects suffering from angina pectoris (4) Subjects suffering from infarct, stroke, transient ischemic attack (TIA), percutaneous transluminal cardio angiography (PTCA) within the last six months; (5) Subjects who were suffering from heart failure (NIHA classes II-IV), severe arrhythmia, AV block; (6) History of secondary hypertension, such as hiperaldosteronism, Pheochromocytoma, kidney vascular stenosis, coarctation of the aorta, cushing syndrome, (7) Abnormal liver function as diagnosed by two or more laboratory liver function tests; (8) Kidney failure; (9) Orthostatic hypotension in accordance with the other anti-hypertensive drugs; (10) Severe hypertension (blood pressure 200/115 mmHg or more); (11) Hypersensitive to Ca-channel blocker; (12) Blood donor for the last four weeks; (13) History of alcohol dependency, unstable psychology which caused could not be able to sign inform consent; and (14) Who were still joining the other drug study.

Upon signing inform consent, the would be subjects were randomized divided into two groups. After having washed out for one week, all subjects began to follow the treatment. The first group received phytopharmaca (Tensigard ${ }^{\circledR}$ a produced of PT. Phapros, Semarang) $3 \times 250 \mathrm{mg} /$ day, and the second group had Amlodipine $1 \times 5 \mathrm{mg}$ /day and $2 \times 1$ placebo/day in order the oral drug frequency as well the capsule size and color identical for the two groups. Each capsule of phytopharmaca contains Apii herba extract of Orthosiphonis folium (75:25) 99,40\%. While the placebo contains sacharose.

Amlodipine was selected for this study as the comparative drug because at present time this antihypertensive drug has been proved to control hypertension and calcium antagonist is widely used. If within two weeks there was no blood pressure decrease, the doses increased into $2 \times 2$ capsules, which contain $250 \mathrm{mg}$ phytopharmaca, and for Amlodipine. 1 x $10 \mathrm{mg}$. In case by increasing these doses there was no response, the respective subject was discontinued for this study, and given taken a suitable anti-hypertensive drugs.

Subjects who fulfilled inclusion and signed inform consent went for twice blood pressure assessments taken on sitting position by five minutes intervals, body weight, body height, heart rate, laboratory tests (haemoglobin, white blood cell, total cholesterol, high density lipid (HDL), low density lipid (LDL), triglyceride, blood sugar, liver function, kidney function, electrolytes: kalium, chloride, magensium, and natrium), chest $x$-ray, and electrocardiography. Subjects were given phytopharmaca or Amlodipine 90 tablet or capsules, and were asked to make a revisit on the day 15 . These procedures were repeated every two weeks. Subjects' evidence to take medication was seen by the rest of the drugs given.

Comprehensive laboratory tets were performed at the beginning and at the end of the study. Where as electrolites test were performed every two weeks. 
Hemoglobine and white blood cells were done by taking $1 \mathrm{ml}$ blood EDTA, and was measured by flow citometry using technicon ( $\mathrm{TH} 3$ ). Tests for plasma cholesterol, triglyceride, HDL-cholesterol and LDLcholesterol were carried by taking $0.3 \mathrm{ml}$ serum by photometri methods using Hitachi 917 tool. Blood sugar test was carried out by taking $0.3 \mathrm{ml}$ serum and measured by photometry methods using Hitachi 917 tool. The same methods were carried for SGOT, SGPT, ureum, creatinine and uric acid. While for blood electrolyte was performed by ISE (Ion Selective Electrode) methods using AVL tool.

Numeric data were analysed by two samples t-test for normal distribution data, and Mann-Whitney test for abnormal distribution data. Categorized data were analysed using Pearson's chi-square or Fisher exact statistical tests. The similarity was considered if there is a $\mathbf{P}>0.050$ based on the results of significant statistical tests. All statistical tests were based on two tail tets. All caculation were performed by using SPPS software version 10 .

Ethical Committee of the National Cardiac Center Harapan Kita approved this study.

\section{RESULTS}

At the beginning of the study eighty subjects participated in this study for each groups. During the study period there were 18 subjects discontinued the study (eight subjects from the phytopharmaca group, and 10 subjects belonged to Amlodipine group). There were several reasons for discontinuing this study, such as: (1) The subjects could not afford the side effect; (2) The subjects felts that the medicines were not suitable; (3) The subjects moved to other address and could not be followed-up; (4) Other reasons.

Table 1 shows that phytopharmaca and Amlodipine groups were similarly distributed with respect to gender, smoking habits, family history. Furthermore, more phytopharmaca group than Amlodipine group who had dislipidemia $(P=0.117)$.

In addition Table 2 shows that the two groups were also similarly distributed with respect of age, blood pressure on entry, laboratory (except for LDL), and electrolytes findings. Tensgard ${ }^{\mathbb{B}}$ group had a significantly higher LDL level compared with Amlodipine group $(P=0.033)$.
Table 1. Some characteristics of subjects

\begin{tabular}{lccc}
\hline & $\begin{array}{c}\text { Phytopharmaca } \\
(\mathrm{N}=72)\end{array}$ & $\begin{array}{c}\text { Amlodipine } \\
(\mathrm{N}=70)\end{array}$ & $\mathrm{P}$ \\
\hline Gender & 54 & 52 & 0.922 \\
$\quad$ Male & 18 & 18 & \\
$\quad$ Female & 38 & 40 & 0.600 \\
Smoking habits & & 30 & \\
$\quad$ No & 34 & & 0.117 \\
Yes & & 40 & \\
Dislipidemia & 29 & 30 & \\
$\quad$ No & 43 & & 0.423 \\
$\quad$ Yes & & 45 & \\
Family history & 29 & 18 & \\
$\quad$ No & 43 & & 0.414 \\
$\quad$ Yes & & 63 & \\
Diabetes & 62 & 7 & \\
mellitus type II & 10 & & \\
$\quad$ No & & & \\
$\quad$ Yes & & & \\
\hline
\end{tabular}

Table 2. Some characteristics of subjects

\begin{tabular}{lccc}
\hline & $\begin{array}{c}\text { Phytopharnaca } \\
(\mathrm{N}=72) \\
\text { Mean } \pm \mathrm{SD}\end{array}$ & $\begin{array}{c}\text { Amlodipine } \\
(\mathrm{N}=70) \\
\text { Mean } \pm \mathrm{SD}\end{array}$ & $\mathrm{P}$ \\
\hline Age (years) & $59.60 \pm 1.05$ & $61.03 \pm 1.26$ & 0.378 \\
Physical performance & & & \\
$\quad$ Body weight (kg) & $61.40 \pm 1.32$ & $61.18 \pm 1.47$ & 0.913 \\
Height (cm) & $157.48 \pm 0.85$ & $158.72 \pm 0.97$ & 0.340 \\
Blood pressure on entry & & & \\
Systolic (mmHg) & $163.68 \pm 1.64$ & $165.76 \pm 2.04$ & 0.460 \\
Diastolic (mmHg) & $96.67 \pm 0.77$ & $96.69 \pm 1.18$ & 0.825 \\
Laboratory (mg/dl) & & & \\
Total cholesterol & $205.81 \pm 4.66$ & $196.06 \pm 4.29$ & 0.090 \\
HDL & $41.62 \pm 1.47$ & $42.02 \pm 1.39$ & 0.971 \\
LDL & $131.07 \pm 4.35$ & $120.08 \pm 3.32$ & 0.033 \\
Triglyceride & $164.00 \pm 8.29$ & $186.54 \pm 17.3$ & 0.270 \\
Fasting blood sugar & $101.99 \pm 3.76$ & $105.29 \pm 4.83$ & 0.455 \\
SGOT & $20.96 \pm 1.00$ & $21.77 \pm 0.88$ & 0.254 \\
SGPT & $23.25 \pm 1.66$ & $22.35 \pm 2.13$ & 0.979 \\
Electrolytes (mmol/dl) & & & \\
Kalium & $4.53 \pm 0.08$ & $4.53 \pm 0.10$ & 0.287 \\
Chloride & $104.59 \pm 0.42$ & $104.07 \pm 0.48$ & 0.734 \\
Magnesium & $2.13 \pm 0.06$ & $2.11 \pm 0.05$ & 0.860 \\
Natrium & $140.98 \pm 0.26$ & $140.88 \pm 0.28$ & 0.794 \\
& & & \\
\hline & & &
\end{tabular}

Table 3 and Table 4 show that diastolic and systolic blood pressure gradually decreased in both groups. Systolic and diastolic blood pressure were prominent different decreases between two groups were noted during week of 4 and $6(P=0.027$ and 0.078 respectively). 
Table 3. Systolic blood pressure on entry and the decrease by week of treatment

\begin{tabular}{|c|c|c|c|c|c|}
\hline \multirow[b]{2}{*}{ Week } & \multicolumn{2}{|c|}{ Phytopharmaca $(N=72)$} & \multicolumn{2}{|c|}{ Amlodipine $(\mathrm{N}=70)$} & \multirow[b]{2}{*}{$\mathrm{P}$} \\
\hline & $\begin{array}{c}\text { Systolic blood } \\
\text { pressure } \\
\text { Mean } \pm \text { SD }\end{array}$ & $\begin{array}{l}\text { Decrease from } \\
\text { the entry } \\
\text { measurement } \\
\text { Mean } \pm S D\end{array}$ & $\begin{array}{c}\text { Systolic blood } \\
\text { pressure } \\
\text { Mean } \pm \text { SD } \\
\end{array}$ & $\begin{array}{l}\text { Decrease from } \\
\text { the entry } \\
\text { measurement } \\
\text { Mean } \pm S D\end{array}$ & \\
\hline Week 0 & $163.68 \pm 1.64$ & - & $165.76 \pm 2.04$ & - & - \\
\hline Week 2 & $149.51 \pm 1.90$ & $14.17 \pm 1.88$ & $149.41 \pm 2.30$ & $16.36 \pm 2.05$ & 0.433 \\
\hline Week 4 & $149.79 \pm 1.60$ & $13.89 \pm 1.86$ & $146.02 \pm 1.96$ & $19.75 \pm 1.79$ & 0.027 \\
\hline Week 6 & $143.54 \pm 1.36$ & $20.14 \pm 1.78$ & $141.67 \pm 1.61$ & $23.83 \pm 2.11$ & 0.180 \\
\hline Week 8 & $142.78 \pm 1.79$ & $20.90 \pm 2.08$ & $141.27 \pm 1.39$ & $24.49 \pm 1.97$ & 0.220 \\
\hline Week 10 & $140.69 \pm 1.14$ & $22.99 \pm 1.73$ & $140.34 \pm 1.53$ & $25.42 \pm 2.13$ & 0.371 \\
\hline Week 12 & $139.15 \pm 1.18$ & $24.72 \pm 1.63$ & $139.49 \pm 1.73$ & $26.27 \pm 2.18$ & 0.563 \\
\hline
\end{tabular}

Table 4. Diastolic blood pressure on entry and the decrease by week of treatment

\begin{tabular}{|c|c|c|c|c|c|}
\hline \multirow{3}{*}{ Week } & \multicolumn{2}{|c|}{ Phytopharmaca $(N=72)$} & \multicolumn{2}{|c|}{ Amlodipine $(\mathrm{N}=70)$} & \multirow{3}{*}{$\mathrm{P}$} \\
\hline & $\begin{array}{l}\text { Diastolic blood } \\
\text { pressure }\end{array}$ & $\begin{array}{c}\text { Decrease from } \\
\text { the entry } \\
\text { measurement }\end{array}$ & $\begin{array}{c}\text { Diastolic blood } \\
\text { pressure }\end{array}$ & $\begin{array}{c}\text { Decrease from } \\
\text { the entry } \\
\text { measurement }\end{array}$ & \\
\hline & Mean $\pm S D$ & Mean $\pm S D$ & Mean $\pm S D$ & Mean $\pm S D$ & \\
\hline Week 0 & $96.67 \pm 0.77$ & - & $96.69 \pm 1.18$ & - & - \\
\hline Week 2 & $91.39 \pm 0.86$ & $5.28 \pm 0.99$ & $91.27 \pm 1.09$ & $5.42 \pm 1.17$ & 0.924 \\
\hline Week 4 & $91.04 \pm 0.87$ & $5.63 \pm 1.09$ & $88.05 \pm 1.18$ & $8.64 \pm 1.33$ & 0.078 \\
\hline Week 6 & $89.10 \pm 0.81$ & $7.57 \pm 0.98$ & $86.58 \pm 0.88$ & $10.17 \pm 1.18$ & 0.090 \\
\hline Week 8 & $88.26 \pm 1.06$ & $8.40 \pm 1.06$ & $86.78 \pm 0.89$ & $9.92 \pm 1.39$ & 0.381 \\
\hline Week 10 & $87.22 \pm 0.62$ & $9.44 \pm 0.89$ & $86.61 \pm 0.99$ & $10.08 \pm 1.36$ & 0.685 \\
\hline Week 12 & $86.76 \pm 0.82$ & $10.00 \pm 0.96$ & $87.20 \pm 0.88$ & $9.49 \pm 1.37$ & 0.756 \\
\hline
\end{tabular}

Among phytopharmaca subjects, at the end of the study systolic blood pressures the average decreased was $24.72 \mathrm{mmHg}$. This is almost the same figure among Amlodipine subjects $(26.27 \mathrm{mmHg})$. The same decreases were also noted for diastolic blood pressures. These means both drugs were suitable to control mild and moderate hypertension. It can be concluded that there was no difference between phytopharmaca and Amlodipine to control mild and moderate hypertension.

Table 5 indicates that there were no significant changes in term of laboratory findings on electrolytes, plasma lipids, and fasting blood sugar between at the entry and at the end of the study on both groups.

Table 6 shows that the most frequent side effect was dizziness. For each groups revealed there were 14 $(19 \%)$ subjects who experience of having dizziness. The other side effects were considered to be rare, and the was no significant difference between two groups.

There was one subject who develops TLA (Temporary Ischemic Attack) among Tensgard ${ }^{\$}$ group. In addition, there was noted one subject among Amlodipine group who experience of having unstable angina. The two cases could be managed by nitrate treatments. 
Table 5. Change of electrolyte, plasma lipid, and fasting blood sugar

\begin{tabular}{lccccc}
\hline & \multicolumn{2}{c}{ Phytopharmaca $(\mathrm{N}=72)$} & \multicolumn{2}{c}{ Amlodipine $(\mathrm{N}=70)$} & \multirow{2}{*}{$\mathrm{P}$} \\
\cline { 2 - 5 } & On entry & The end & On entry & The end & \\
\hline Kalium & $4.53 \pm 0.08$ & $4.17 \pm 0.06$ & $4.35 \pm 0.10$ & $4.07 \pm 0.07$ & 0.782 \\
Chloride & $104.59 \pm 0.42$ & $103.89 \pm 0.33$ & $104.07 \pm 0.48$ & $104.06 \pm 0.29$ & 0.314 \\
Magnesium & $2.13 \pm 0.06$ & $2.14 \pm 0.03$ & $2.11 \pm 0.05$ & $2.16 \pm 0.03$ & 0.469 \\
Natrium & $140.98 \pm 0.26$ & $141.50 \pm 0.25$ & $140.88 \pm 0.28$ & $141.58 \pm 0.26$ & 0.927 \\
Total cholesterol & $205.81 \pm 4.66$ & $215.75 \pm 5.54$ & $196.06 \pm 4.29$ & $203.79 \pm 4.39$ & 0.643 \\
HDL & $41.62 \pm 1.47$ & $42.33 \pm 1.22$ & $42.02 \pm 1.39$ & $42.85 \pm 1.58$ & 0.935 \\
LDL & $131.0 \pm 4.35$ & $145.46 \pm 4.98$ & $120.08 \pm 3.32$ & $133.12 \pm 3.79$ & 0.797 \\
Triglyceride & $164.00 \pm 8.29$ & $139.64 \pm 7.81$ & $186.54 \pm 17.30$ & $152.77 \pm 13.19$ & 0.523 \\
Fasting blood sugar & $101.99 \pm 3.76$ & $106.19 \pm 4.30$ & $105.29 \pm 4.83$ & $108.46 \pm 4.09$ & 0.864 \\
\hline
\end{tabular}

Table 6. Some side effects

\begin{tabular}{lccc}
\hline & $\begin{array}{c}\text { Phytopharmaca } \\
(\mathrm{N}=72)\end{array}$ & $\begin{array}{c}\text { Amlodipine } \\
(\mathrm{N}=70)\end{array}$ & $\mathrm{P}$ \\
\hline Dizziness & 14 & 14 & 0.934 \\
Faint & 3 & 1 & 0.324 \\
Libido decrease & 1 & 1 & 0.984 \\
Tibial edema & 0 & 0 & - \\
Flushing on face & 1 & 0 & 0.322 \\
Nausea & 1 & 4 & 0.162 \\
Frequent urinating & 0 & 0 & - \\
Sleepy & 1 & 2 & 0.543 \\
Tachycardia & 2 & 2 & 0.977 \\
Bradicardia & 0 & 0 & - \\
\hline
\end{tabular}

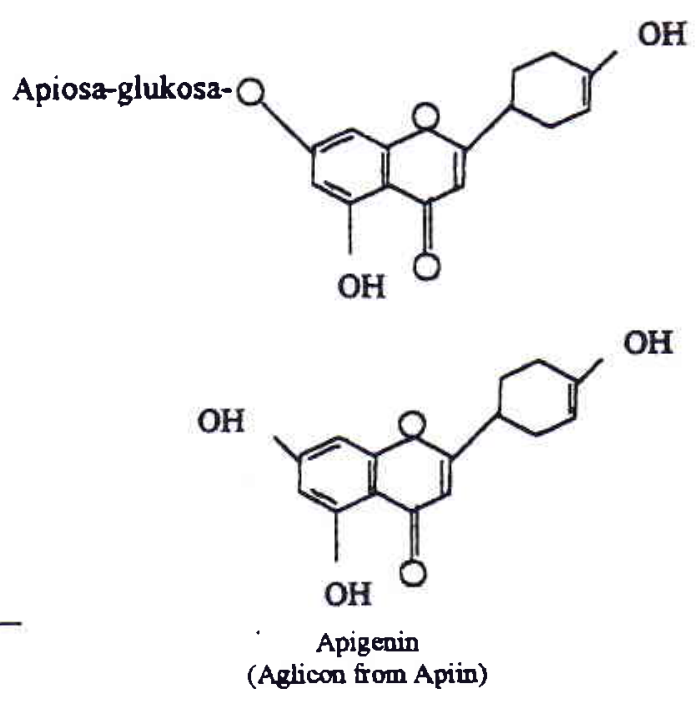

\section{DISCUSSION}

Phytopharmaca is a development of traditional medicine. The basic difference between traditional medicine and phytopharmaca is the active chemical component on phytopharmaca is quantitatively known, whereas on the traditional medicine the only known is source of extract. ${ }^{6}$ Furthermore, the other important things on phytopharmaca there are phase I, II, and III clinical trial evidence. On the other hand, the traditional medicine is based on empirical experiences or desceridence belief.

In this study the phytopharmaca is a domestic Indonesian product by gathering traditional medicines to be a created phytopharmaca named "Tensigard®". In fact this phytopharmaca has been available in the market as a traditional medicine (jamu). This phytopharmaca needs a clinical trial.

Tensigard $^{\mathbb{1}}$ is a phytopharmaca consisted of extract of Apium graviolens or in Indonesian language is called seledri for $74 \%$ and extract of Orthosiphon stamineus (kumis kucing) for $11 \%$, and added with lactose, magnesium stearat, and texapon.

Apium graviolens leaf contains atsiri oil, protein, calcium, phosphate salt mineral, vitamin A, B and C. The stick leaf of and the seed contain apiin and apigenin. ${ }^{8}$

One capsule of Tensigard® consisted of active substance of apigenin for $11.04 \mathrm{mg}$ and Orthosiphon stamineus benth $8.4 \mathrm{mg}$.

Previous reports ${ }^{5,10}$ apigenin has an effect for aorta vasorelaxation or vasodilatation among isolated rats by mechanism contraction inhibition by means of calcium released (calcium antagonist), ${ }^{9-10}$ The other report $^{6}$ reported that apigenin has an effect to inhibit protein kinase $\mathrm{C}$ or has an effect protein Kinase-C inhibitor on rat aorta. This inhibition of cyclic nucleotide phospo-diesterase decreases calcium release." 
Therefore, apigenin has been proved to have a similar effect with Calcium channel bloker. ${ }^{9-11}$ Whereas, Orthosiphon stamineus extract contains Methylripariochromene $\mathrm{p}$ (MRC). The $\mathrm{MRC}$ has a vasodilator effect, lowering cardiac output. In addition it has a diuresis efect. ${ }^{12}$ This effect is similar with beta blocker efect. ${ }^{12}$ Therefore, the phytopharmaca has a similar effect with calcium channel blocker, a mild beta blocker and diuretic. These three effects are lowering blood pressure. This study reveals that systolic as well as diastolic blood pressures for both groups (phytopharmaca and Amlodipine) decreased, and there was no significant difference.

The slope of systolic and diasstolic blood pressure decreased among phytopharmaca was not as sharp as the Amlodipine group. However, it reached significant results at week 12 . This means that phytopharmaca is relevant to control mild and moderate hypertension.

Diuretic effect for this phytopharmaca ${ }^{[1-13}$ was not prominent. There was no diuretic complaint from the study subjects. In addition, there was no diuresis effect toward blood electrolyte profiles. The same results were also noted for plașma lipids ${ }^{14,15}$ Effect on plasma lipids is similar with the previous report on rats. ${ }^{15}$ The phytopharmaca had no significant effects on blood sugar. This means there would be nor hyperglicemia or hypoglycemia.

The phytopharmaca had no clear beta-blocker effect. This can be seen that there were only a small number of subjects who had a decreased libido, bradicardia, etc. among the two groups.

There was no tibial edema and tachicardia found. One subject was found to be TLA among Amlodipine group. Further anamnesis revealed that two years the subject suffered several times from TLA.

Whereas one subject who had unstable angina among phytopharmaca group revealed that this is the first time. The subject had several risk factors, such as a fifty year-old male, heavy smoker and had dislipidemia. It seems that unstable angina was not related to the phytopharmaca. He had a four-day hospitalization and he had heparinization and nitrate in accordance with the study protocol.

Transient ischemic attack as well as angina pectoris were found on the second and third day after discontinuation of hypertensive treatment.
Even though the phytopharmaca contains diuretics, it is not proved that hypokalemia occurred on the phytopharmaca treatment. This means that the predicted the effect of calcium antagonist was more dominant compared with diuretic effect. In addition, the plasma lipid levels as well as blood sugar level did not change significantly.

This study noted that on both groups when SBP blood reached 130-140 $\mathrm{mmHg}$ and DBP reached 90 - 80 $\mathrm{mmHg}$, even though the treatment were continued, there was drastic blood pressure decrease or hypotension. The combination effect of calcium blocker, beta-blocker and mild diuretic for The phytopharmaca seems to be tolerated to decrease blood pressure in accordance with Amlodipine.

In conclusion, this trial revealed that the phytopharmaca, which contains Apium graviolens and Orthosiphon stamineus benth, lowered systolic and diastolic blood pressure equivalent with Amlodipine among mild and moderate hypertensive subjects.

\section{REFERENCES}

1. Monica Jakarta Team. Report on MONICA survey III. The risk and fall of cardiovascular risk factors after 12 years [Indonesian]. Jakarta: The Team; 2000.

2. National Heart, Lung and Blood Pressure Institute. The sixth report of the joint national committee on prevention, detection, evaluation and treatment of high blood pressure. Nat Inst Hith Publ No. 98-4084. Bethesda: The Institute; 1997.

3. Gadjah Mada University. Report on preclinical trial on Tensigard® [Indonesian]. Yogyakarta: The University Press; 2001.

4. Ministry of Health of the Republic of Indonesia [Indonesian]. Herbal preparate [Indonesian]. Jakarta: The Ministry; 2000.

5. Chan EC, Pannahpech P, Woodman OL. Relaxation to flavones and flavonols in rat isolated thoracic aorta: Mechanism of action and structure-activity relationship. J Cardiovascular Pharmacology 2000;35:326-33.

6. Chang HN, But PPH. Pharmacology and applications of Chinese material. Medica vol 2. Singapore: World Scientific Publ Co Ltd; 1986.

7. Ministry of Health of the Republic of Indonesia. Guidance on herbal preparate [Indonesian]. 1st edition. Jakarta: The Ministry; 2000.

8. Englert J, Harnischfeger Gi. Diuretic action aqueous orthosiphon extract in rats. Planta Med 1992;58:237-8.

9. Galyuteva GI, Benson NA. Comparative evalucision of the diuretic activity of leaves and leaf tissue culture biomass of Orthosiphon stamineus benth. Rastitel'Nye Resursy 1990;26:559-65. 
10. Ko FN, Huang TF, Teng CM. Biochemical biophysiology acta. Taipei: National Taiwan University; 1991.

11. Ko FN. Vasodilatory action mechanisms of apigenin isolated from Apium graveolens in rat thoracic aorta. Biochim Biophys Acta 1991;1115:69-74.

12. Mitsubara $T_{i}$ Bohgaki $T$, Watarai $M$. Antihypertensive actions of methylripariochromene A from Orthosiphon aristatus, an Indonesian traditional medicinal plant. Biol Pharm Bull 1999;20:1083-8.
13. Sudarsono. Herb plant [Indonesian]. Yogyakarta: Gajah Mada University; 1995.

14. Monica Team. Report on MONICA Survey II. Jakarta; The Team: 1993.

15. Tsi D. Effects of aqueous celery (Apium graveolens) extract on lipid parameters of rats fed a high fat diet. Planta Med. 1995;61:18-21. 